\title{
Correction to: Tracing the colonization process of non- native gobies into a large river: the relevance of different dispersal modes
}

\author{
C. Nogueira Tavares $(\mathbb{D} \cdot$ M. Brauns $\cdot$ S. Hille $\cdot$ S. Krenek $\cdot$ J. Borcherding $\cdot$ \\ M. Weitere
}

Published online: 20 October 2021

(C) The Author(s) 2021

\section{Correction to: Biol Invasions (2020) 22:2421-2429 \\ https://doi.org/10.1007/s10530-020-02281-x}

The article "Tracing the colonization process of nonnative gobies into a large river: the relevance of different dispersal modes", written by C. Nogueira Tavares, M. Brauns, S. Hille, S. Krenek, J. Borcherding and M. Weitere, was originally published Online First without Open Access. After publication in volume 22, issue 8, page 2421-2429 the author decided to opt for Open Choice and to make the article an Open Access publication. Therefore, the copyright of the article has been changed to (c) The

The original article can be found online at https:// doi.org/10.1007/s 10530-020-02281-x.

C. Nogueira Tavares $(\varangle) \cdot$ M. Brauns

S. Hille $\cdot$ S. Krenek $\cdot$ M. Weitere

Department River Ecology, Helmholtz Centre for

Environmental Research - UFZ, Brueckstr. 3a,

39114 Magdeburg, Germany

e-mail: claudia.tavares@ufz.de

S. Krenek

Institute of Hydrobiology, Technische Universität

Dresden, Zellescher Weg 40, 01217 Dresden, Germany

J. Borcherding

Department of General Ecology, Ecological Field Station Grietherbusch, Institute for Zoology of the University of Cologne, 50923 Cologne, Germany
Author(s) 2020 and the article is forthwith distributed under the terms of the Creative Commons Attribution 4.0 International License, which permits use, sharing, adaptation, distribution and reproduction in any medium or format, as long as you give appropriate credit to the original author(s) and the source, provide a link to the Creative Commons licence, and indicate if changes were made. The images or other third party material in this article are included in the article's Creative Commons licence, unless indicated otherwise in a credit line to the material. If material is not included in the article's Creative Commons licence and your intended use is not permitted by statutory regulation or exceeds the permitted use, you will need to obtain permission directly from the copyright holder. To view a copy of this licence, visit http:// creativecommons.org/licenses/by/4.0. Open access funding enabled and organized by Projekt DEAL.

The original article has been corrected.

Open Access This article is licensed under a Creative Commons Attribution 4.0 International License, which permits use, sharing, adaptation, distribution and reproduction in any medium or format, as long as you give appropriate credit to the original author(s) and the source, provide a link to the Creative Commons licence, and indicate if changes were made. The images or other third party material in this article are included in the article's Creative Commons licence, unless indicated otherwise in a credit line to the material. If material is not included in the article's Creative Commons licence and your intended use is not permitted by statutory regulation or exceeds 
the permitted use, you will need to obtain permission directly from the copyright holder. To view a copy of this licence, visit http://creativecommons.org/licenses/by/4.0/.
Publisher's Note Springer Nature remains neutral with regard to jurisdictional claims in published maps and institutional affiliations. 